\title{
Comment on Goodbye JUSTICE, HELLO HAPPINESS: Welcoming Positive PSychology to the LAW
}

\section{DAVID G MYeRS*}

Kudos to Professor Mirko Bagaric and James McConvill for their well-informed review of the new happiness research, and for their provocative ideas on how such research might define new criteria for making laws that optimally advance human flourishing. As one who has followed and reported on this new research, I concur that it has the potential to guide public policies.

Bagaric and McConvill seem to be kindred spirits of Ed Diener, the leading happiness researcher, and Martin Seligman, who has inspired the new $21^{\text {st }}$ century "positive psychology" that aims to promote happier lives, personal strengths and virtues, and healthier institutions. In their essay, Beyond Money: Toward an Economy of Well-Being, ${ }^{1}$ Diener and Seligman argue:

that the policy decisions of governments, private institutions, and corporations must include analyses of well-being to supplement economic indicators. Thus, we propose that a national well-being index be created that systematically assesses key well-being variables for representative samples. ... Existing well-being findings point to important policy-relevant patterns that are not revealed by economic indicators. ${ }^{2}$

Bagaric and McConvill correctly note that money, once beyond enough to afford life's necessities and a sense of control over one's life, is less predictive of happiness than other marks of happy lives. The good life springs from earning one's first million than from loving and being loved, from developing the traits that mark

\footnotetext{
* John Dirk Werkman Professor of Psychology, Hope College, USA. Professor Myer's personal website is: 〈www.davidmyers.com>

${ }^{1}$ Ed Diener and Martin E P Seligman, Toward an Economy of Well-Being, 5 PSYCHOLOGICAL SCIENCE IN THE PUBLIC INTEREST 1.

${ }^{2}$ Id.
} 
happy lives, from finding connection and meaningful hope in faithful communities, and from the "flow" of involving work and recreation. ${ }^{3}$

Especially in poor countries, such as India, being relatively well off does make for greater well-being. We do need food, rest, shelter, and some sense of control over our lives. But in affluent countries, the link between wealth and self-reported wellbeing is "surprisingly weak", notes researcher Ronald Inglehart. ${ }^{4}$ Once able to afford life's necessities, more and more money provides diminishing additional returns. Summarising his own studies of happiness, psychologist David Lykken observes that "People who go to work in their overalls and on the bus are just as happy, on the average, as those in suits who drive to work in their own Mercedes. ${ }^{5}$ Even the very rich- for example, the Forbes 100 wealthiest Americans in a 1980s survey by Ed Diener and his colleagues- are only slightly happier than average.

And consider: Over time, does our happiness rise with our affluence? A recent windfall from an inheritance, a surging economy, or a lottery win does provide a temporary jolt of joy. But soon one adapts to the new wealth, and the euphoria subsides.

If personal happiness does not enduringly rise with our rising personal affluence, does a rising economic tide lift our collective happiness? Are Australians, Brits and Americans happier than a half century ago, when we had so many fewer cars, so much less technology, small homes, and no post-it notes?

We are not. For example, since 1957, the number of Americans who say they are "very happy" has declined slightly, from 35 to 30 percent. We are twice as rich and no happier. Meanwhile, the divorce rate has doubled, the ten suicide rate has more than doubled, and increasingly our teens and young adults are plagued by depression.

These facts of life lead us to a startling conclusion: Our becoming better off materially has not made us better off psychologically. In the USA, Europe, and Japan, affluence has not purchased the good life. The conclusion startles because it challenges modern materialism: Economic growth in affluent countries has provided no apparent boost to human morale. Moreover, when materialistic longings are strongest and in countries where economic inequality is greatest (injustice matters), happiness suffers.

\section{Liberty and Fraternity}

Given that personal well-being flows less from economic factors than from psychological factors such as a sense of personal control over one's life, Bagaric and McConvill contend that most "restrictive laws which do not directly harm others should be repealed." For example, laws restricting property rights and pornography "should be relaxed."

\footnotetext{
${ }^{3}$ See David Myers, The Good Life, YES! MAGAZINE (Summer 2004).

${ }^{4}$ RONALD INGLEHART, CULTURE SHIFT IN ADVANCED INDUSTRIAL SOCIETY 242 (1990).

${ }^{5}$ D T LYKKEN, HAPPINESS 17 (1999).
} 
Does happiness research mandate such libertarianism? I think not. Indeed, the growing evidence of our human "need to belong"- to connect in close, intimate, supportive, enduring relationships-suggests that what modern western cultures need is not more individualism but less.

The mantras of "me-thinking" individualism are familiar: Do your own thing. Question authority. If it feels good, do it. Follow your bliss. Don't conform. Think for yourself. Be true to yourself. You owe it to yourself.

Amitai Etzioni, a recent president of the American Sociological Association, urges us toward an alternative to libertarian individualism - a "communitarian" ethos that balances individualism with a spirit of community. Fellow sociologist Robert Bellah concurs. "Communitarianism is based on the value of the sacredness of the individual," he explains. But it also "affirms the central value of solidarity . . . that we become who we are through our relationships." In Bowling Alone, political scientist Robert Putnam documents the decline of "social capital" that attends growing individualism. ${ }^{7}$

What I have called The American Paradox 8 describes the irony of post-1960 America, which was a time of surging liberty and affluence (the good news) and declining civility and social health (the bad news). As our rights become more secure and our disposable incomes rose, social connections frayed and depression, teen suicide, and crime became more severe. More than ever, we at the end of the last century were finding ourselves with big houses and broken homes, high incomes and low morale, secured rights and diminished civility. We were excelling at making a living but too often failing at making a life. We celebrated our prosperity but yearned for purpose. We cherished our freedoms but longed for connection. In an age of plenty, we were feeling spiritual hunger.

Communitarians, who proclaim a "third way" alternative to individualism and collectivism, believe that individual rights must be balanced with social responsibilities, that libertarian individualism must be restrained by concern for our communal well-being. We humans like to feel unique and in control of our lives, but we also are social creatures having a basic need to belong. Communitarian "wethinking" is leading to greater protections of communal well-being, as in smoking restraints on aeroplanes and in restaurants, environmental legislation that protects the commons, and restraints on individuals' rights to sell and own weapons. The communitarian bottom line: we need to balance our needs for independence and attachment, privacy and community, liberty and fraternity.

Thus, if pornography can be shown (as I believe it has been) to contribute to an impulsive sexuality that undermines one of the biggest predictors of happiness-a stable and close marriage and the co-parenting of children-then Bagaric and McConvill would, I presume, want to make a case for restraints on pornography, or

\footnotetext{
${ }^{6} \mathrm{R}$ N Bellah, Community Properly Understood: A Defense of 'Democratic Communitarianism, THE RESPONSIVE COMMUNITY, Winter, 1995/1996, at 49-54.

${ }^{7}$ Robert PUTNAM, BOWLING AlONE (2001).

${ }^{8}$ D G Myers, The AMERICAN PARAdOX: SPIRITUAL Hunger IN AN AGE OF Plenty (2000).
} 
at least for a public education program that will increase awareness of the dividends of covenant relationships.

Listen to communitarians talk about European-style child benefits, extended parental leaves, flexible working hours, campaign finance reform, and ideas for "fostering the commons" and you'd swear they are liberals. Listen to them talk about covenant marriages, divorce reform, father care, and character education and you'd swear they are conservatives. In fact, communitarians see themselves not as a midpoint but as a third alternative to the individualism-authoritarian and liberalconservative polarities. This "Third Way," as people first called it in Tony Blair's Britain, aims to synthesize some of the best ideas from both camps.

Communitarians welcome incentives for individual initiative and appreciate why Marxist economies have crumbled. "If I were, let's say, in Albania at this moment," said Communitarian Network co-founder Etzioni, "I probably would argue that there's too much community and not enough individual rights." 9 Even in communal Japan (where "the nail that sticks out gets pounded down"), Etzioni says he would sing a song of individuality. In the individualistic American context, he sings a song of social order. Where there is chaos in a neighborhood, people may feel like prisoners in their homes.

Opposition to communitarians comes from civil libertarians of the left, economic libertarians of the right, and special interest libertarians (such as the U.S. National Rifle Association). Much as these organizations differ, they are branches of the same tree-all valuing individual rights in the contest with the common good. Communitarians take on all such varieties of libertarians. Unrestrained personal freedom, they say, destroys a culture's social fabric; unrestrained commercial freedom exploits workers and plunders the commons. Etzioni sums up the communitarian ideal in his New Golden Rule: "Respect and uphold society's moral order as you would have society respect and uphold your autonomy."

To reflect on your own libertarian versus communitarian leanings, consider what restraints on liberty you support: luggage scanning at airports? smoking bans in public places? speed limits on highways? sobriety checkpoints? drug testing of pilots and rail engineers? prohibitions on leaf burning? restrictions on TV cigarette ads? regulations on stereo or muffler noise? pollution controls? requiring seat belts and motorcycle helmets? disclosure of sexual contacts for HIV carriers? outlawing child pornography? banning AK-47s and other non-hunting weapons of destruction? required school uniforms? wire taps on suspected terrorists? fingerprinting checks to protect welfare, unemployment, and Social Security funds from fraud? All such restraints on individual rights, most opposed by libertarians of one sort or another, aim to enhance the public good.

Libertarians often object to restraints on guns, panhandlers, pornography, drugs, or business by warning that such may plunge us down a slippery slope leading to the

\footnotetext{
${ }^{9}$ Amitai Etzioni, The Community in an Age of Individualism (interview), THE FUTURIST, May-June, 1991, at 35-39. Japan remark in his address to the February, 1999 Communitarian Summit, Washington, DC.
} 
loss of more important liberties. If today we let them search our luggage, tomorrow they'll be invading our houses. If today we censor cigarette ads on television, tomorrow the thought police will be removing books from our libraries. If today we ban handguns, tomorrow's Big Brother government will take our hunting rifles. Communitarians reply that if we don't balance concern for individual rights with concern for the commons, we risk chaos and a new fascism.

Australians and Americans are the pre-eminent individualists. For this we enjoy many benefits, but at what communitarians believe is an increasing cost to the social environment. We humans like to feel unique and in control of our lives, but we also are social creatures having a basic need to belong. As individuals, we therefore need to balance our needs for independence and attachment, personal control and community, individuality and social identity, freedom and order. As a society, we struggle to dance on that fine line of vitality lying between anarchy and repression. 